\title{
Do estrangeiro em sua corporeidade: notas sobre ética na tradução literária
}

\section{On the foreigner in it's corporeity: notes about ethics in literary translation}

\author{
Rony Márcio Cardoso Ferreira \\ Universidade Federal do Mato Grosso do Sul - UFMS - Mato Grosso do Sul - Brasil
}

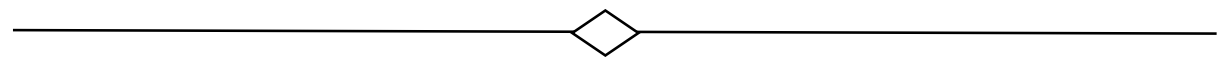

Resumo: Este artigo apresenta uma reflexão teórica a respeito da ética na tradução literária, considerando o profícuo diálogo entre perspectivas epistemológicas que concebem 0 ato tradutório enquanto atividade relacional por excelência. Em outras palavras, objetiva evidenciar em que medida a tradução, como fenômeno linguístico, literário e cultural, mobiliza uma atitude ética do tradutor frente a uma alteridade. Esta reflexão também mobiliza considerações a partir de termos fundamentais dos estudos da tradução literária (fidelidade, experiência, intraduzibilidade, estrangeiro, estrangeiridade, analítica da tradução, transferência, hospitalidade, diferença, entre outros), no intento de postular a importância da tradução e dos tradutores na história, na constituição das literaturas e nas formações de identidades culturais. Para tanto, valeremo-nos, principalmente, dos postulados de Antoine Berman $(2002,2013)$ e Jacques Derrida $(2002,2003,2004)$, a fim de sublinhar que à tradução subjaz uma ética ocupada com a corporeidade estranha dos textos.

Palavras-chave: Experiência ética. Estética da tradução. Fidelidade. Hospitalidade. Tradução literária.

\begin{abstract}
This article presents a theorical reflection towards the ethics in literary translation, considering a proficuous dialogue between epistemological perspectives in which the translation act is considered a relational activity par excellence. In other words, the article objectivates to evidence the proportion in which the translation, as a linguistic, literary and cultural phenomenon, mobilizes an ethic attitude from the translator in front of an alterity. This reflection also calls for considerations from fundamental terms in the literary translation studies (fidelity, experience, untranslatability, foreign, foreignity, translation analytics, transference, hospitality, difference, and others), as intention to postulate the importance of the translations and the translators in history, in the constitution of the literatures and in the formation of cultural identities. Therefore, we're going to deal with the premises from Antoine Berman $(2002,2013)$ and Jacques Derrida $(2002,2003,2004)$, in order to sustain that in the translation acts underlies an ethic engaged with the strange corporeity of the texts.
\end{abstract}

Keywords: Ethic experience. Translation aesthetics. Fidelity. Hospitality. Literary translation. 
O objetivo ético do traduzir, por se propor a acolher o

Estrangeiro na sua corporeidade carnal, só pode estar ligado à letra da obra (BERMAN, 2013, p. 98, grifo do autor).

Acompanhemos esse movimento de amor, o gesto desse amante (liebend) que trabalha na tradução. Ele

não reproduz, não reconstitui, não representa; no essencial ele não devolve o sentido do original, a não ser nesse ponto de contato ou de carícia, o

infinitamente pequeno sentido. Ele estende o corpo das línguas, ele coloca a língua em expansão simbólica [...] (DERRIDA, 2002, p. 49, grifos do autor).

$E$ há uma bem-aventurança física que a nada se compara. O corpo se transforma num dom. E se sente que é um dom porque se está experimentando, numa fonte direta, a dádiva indubitável de existir materialmente (LISPECTOR, 1999, p. 91, grifo nosso).

As relações entre literatura e tradução parecem explícitas sobretudo quando nos lembramos dos empreendimentos tradutórios (tanto no âmbito linguístico, literário e estético, quanto no histórico, ideológico e cultural) inerentes à criação literária. Se, por um lado, a existência de tradutores ao longo da história é um fato inconteste, por outro, o estudo das produções desses intelectuais suscita ainda muitas discussões. Devido à longa predominância de paradigmas que tomaram o trabalho do tradutor como atividade de segundo plano no mundo das letras, a tradução foi obliquamente vista como tarefa menor e, por conseguinte, inferior às produções ditas "originais". Essas questões intensificam-se na medida em que observamos a existência de uma tradição de escritores que foram tradutores e agentes responsáveis pela inserção de obras, autores e tendências em alguns contextos culturais. Basta apenas nos lembrarmos dos empreendimentos tradutórios de Wolfgang Goethe, Friedrich Hölderlin, August Schlegel, Paul Valéry, Ezra Pound, Paul Celan, Jorge L. Borges, Octavio Paz, Machado de Assis, Mário Quintana, Haroldo de Campos, entre outros, para percebermos que a relação da literatura com a tradução caracteriza-se na esfera da reciprocidade.

Tais escritores, ressalvadas as possíveis diferenças e idiossincrasias, tiveram a tradução como constante dever em seus projetos, a qual, muitas vezes, funcionou como ponto de partida para questões que seriam desenvolvidas posteriormente em suas próprias obras ou como local de problematização crítica das demandas advindas de suas produções literárias, uma vez que "toda obra, quão longe possamos recuar, já é, em diversos graus, um tecido de traduções ou uma criação que tem alguma coisa a ver com a operação tradutória" (BERMAN, 2002, p. 329). Enquanto intelectuais envolvidos por uma ética da tradução, muitos tradutores estabeleceram um contato profícuo com o outro, por meio de relações que se prestavam a acolher literaturas, projetos e culturas "no albergue do longínquo" (BERMAN, 2013, p. 97). Ao apresentar uma espécie de arqueologia da tradução em $A$ prova do estrangeiro, Antoine Berman (2002) ressalta que à tarefa tradutória é inerente uma condição ancilar, pois o tradutor está ora inclinado ao (con)texto de partida, ora à cultura para a qual traduz.

Longe de reforçar qualquer visada dicotômica ou binária a respeito do lugar do tradutor na história, a proposição de Berman, na verdade, suscita uma atenção especial ao "drama" (BERMAN, 2002, p. 15) vivido pelos tradutores enquanto intelectuais das letras, para rememorarmos a imagem do "homem de letras" (ARROJO, 1993, p. 151) evocada por Jorge Luis Borges, por exemplo, em "Pierre Menard, autor do Quixote" (BORGES, 2007, p. 34). Tal drama vai de encontro aos postulados de Jacques Derrida (2005) sobre a fidelidade, herança e genealogia que marcam todo e qualquer processo tradutório. Segundo o filósofo franco-argelino, a tradução não deixa de ser um movimento ambivalente que, ao mesmo tempo, oscila entre o universal e o natural, o próprio e o alheio, o traduzível e o intraduzível. Essa ambivalência faz emergir do ato tradutório uma paradoxal lógica de acompanhamento solitário. Assim, à metalinguagem sobre a tradução é, em sentido amplo, inerente também um drama, pois ela formaliza em sua incompletude o drama do tradutor tal como defendido por Berman. Nas palavras de Derrida:

O paradoxo suplementar e abissal, essa lógica de acompanhamento solitário, esse isolamento ou essa retirada do estar-com é também o destino da tradução. Essas proposições em trabalho de tradução são proposições a respeito da própria tradução. Não há metalinguagem tradutológica que não esteja assujeitada, como idioma, ainda, ao drama que ela pretende formalizar ou traduzir por sua vez. Não se fala nunca de 
tradução numa linguagem universal, fora de uma língua natural (intraduzível - a traduzir) (DERRIDA, 2005, p. 170, grifo do autor).

Apoiado nessas inferências e em sua noção de economia das frases $^{1}$, Derrida propõe uma concepção outra ao termo "fidelidade", procurando se afastar dos paradigmas instituídos pela filosofia ocidental. Sob essa perspectiva, o movimento básico da tradução e, por conseguinte, do próprio tradutor seria o de apreender a intraduzibilidade de um texto traduzindo-o, simultaneamente. Ao invés de propor uma recusa à tradução, Derrida proclama, com efeito, um apelo ao ato tradutório por meio de uma dupla fidelidade: considerar a intraduzibilidade das línguas e, de modo isócrono, absorver por meio do texto em tradução a resistência do intraduzível. Ser fiel "a mais de um" (DERRIDA, 2005, p. 167) seria, neste contexto, um estímulo à tradução a partir de uma experiência do intraduzível em si mesmo, uma vez que "a tradução é a experiência, o que se traduz ou se experimenta, também: a experiência é tradução" (DERRIDA, 2002, p. 69, grifos nossos). Em outras palavras, ao preconizar uma não-renúncia ao ato tradutório, o pensador destaca ser a própria tradução aquilo que se experimenta do estranho, tornando-se também a experiência vivida um ato de tradução. Portanto, "apreender o intraduzível e apreendê-lo como tal é ler, é escrever, no sentido forte da palavra, naturalmente, é o corpo-a-corpo com o idioma; mas já é então uma prova, a primeira prova do apelo a traduzir" (DERRIDA, 2005, p. 171, grifo do autor).

Salvaguardadas as distinções, a noção de fidelidade tal como proposta por Derrida se aproxima da metáfora ancilar defendida por Berman, pois, em ambas, encontramos um desejo que ora se volta ao texto de partida em sua resistência, ora toma essa

\footnotetext{
${ }^{1}$ Silviano Santiago (1976), em Glossário de Derrida, afirma que o emprego do termo economia (économie) no pensamento derridiano é marcado por quatro acepções: a intenção do filósofo deixar em seus textos o termo que deseja desconstruir atribuindo-Ihe um sentido outro; o propósito de realçar o caráter polissêmico dos significantes na esfera da interpretação; a finalidade de evidenciar o movimento dos significantes no âmbito de um conjunto finito de elementos; o desejo de compensar o desperdício de significação frente à irredutível polissemia dos termos (Cf. SANTIAGO, 1976, p. 27). Em leitura de "A tarefa do tradutor", de Walter Benjamin (2010), Derrida (2002), muito próximo do que sugere Berman (2013, p. 98-99) a respeito do acolhimento do estrangeiro em sua corporeidade (a letra),
}

mesma resistência como uma voz de enfrentamento a ser pronunciada em outra língua. Por extensão, a imagem do tradutor como um homem das letras é marcada por uma "mirada estrábica", tomando de empréstimo a expressão assim como formulada por Ricardo Piglia (1991), em "Memoria y tradición”. O crítico e escritor argentino, ao postular que uma cultura se constrói na tensão entre elementos externos e internos, ressalta a importância da figura do estrangeiro na constituição das identidades culturais. De acordo com Piglia, "há que se ter um olho posto na inteligência europeia [consequentemente, na literatura estrangeira,] e o outro posto nas entranhas da pátria [na literatura para a qual se traduz]" (PIGLIA, 1991, p. 61 , tradução nossa ${ }^{2}$ ). Deslocando as proposições do crítico ao contexto da tradução literária, parece-nos ser o tradutor aquele que escreve em uma língua a partir dos rastros de uma outra, como um sujeito de fronteira indelevelmente marcado por uma mirada estrábica cujo papel não se pode anular.

Devido a essas questões, no desejo de representar uma espécie de "fidelidade encarnada" (BERMAN, 2002, p. 16), a tradução acaba por ocupar um espaço de maior destaque e importância: ela é alicerçada em uma premissa mais ampla, atitude questionadora frente às perspectivas etnocêntricas e narcísicas que, no âmbito de uma quimera reflexiva, promulgaram a existência das obras, dos textos e das literaturas para além de qualquer relação com o outro. Por isso talvez Berman afirme que, mesmo resistindo a ela, toda cultura não deixa de ser tradutória por excelência, como se, na tradução, houvesse "alguma coisa da violência da mestiçagem" (BERMAN, 2002, p. 16). Essa violência é inerente ao que o autor de $A$ prova do estrangeiro nomeia por "visada da tradução",

constata ser a palavra o elemento originário do trabalho do tradutor, pois ela seria a literalidade que sustenta a proposição (articulação sintática). Isto é, o privilégio da palavra (Derrida) ou da letra (Berman) leva o tradutor ao trabalho corpóreo do texto, em amplo sentido, ao mesmo tempo que se "abre para o problema econômico da tradução, trata-se da economia como lei do próprio ou da economia como relação quantitativa (traduzir é transpor um nome próprio em várias palavras, em uma frase ou em uma descrição etc.?) (DERRIDA, 2002, p. 46, grifo do autor).

2 "Hay que tener un ojo puesto en la inteligencia europea y el otro puesto en las entrañas de la patria" (PIGLIA, 1991, p. 61). 
em cujo mecanismo básico encontramos a relação do próprio com o outro (estrangeiro) no campo da escrita.

É sob esse prisma que a tradução enquanto tarefa linguística, literária e cultural mobiliza uma "visada ética" (BERMAN, 2002, p. 17) em seu próprio fazer. Apoiada em uma índole eminentemente relacional, a atividade tradutória se põe como fenômeno de abertura ao outro, ao diferente, ao estrangeiro, garantindo que as identidades se firmem ainda quando em diálogo contínuo, pois "a essência da tradução é ser abertura, diálogo, mestiçagem, descentralização. Ela é relação, ou não é nada" (BERMAN, 2002, p. 17). Ao invés de mero processo etnocêntrico de apropriação e redução, o ato de traduzir literatura proclama uma vida a mais às línguas e aos povos, fazendo emergir uma visada ética por meio da qual se fortalece tanto a circulação de tendências estéticas quanto a reformulação de tradições locais. Assim, não seria insensato dizer que pensar a tradução é um ato crítico substancial à própria teoria literária, já que o papel do tradutor na sociedade e o exame de suas produções possibilitam à crítica

[...] acompanhar a evolução das formas e dos efeitos, dos gêneros e dos gostos, por meio da penetração tardia de ideias, de estilos e de atitudes críticas que [quase sempre] não são as nossas. Além disso, como estratégia e lugar de mediações interliterárias, a tradução é considerada atualmente como um recurso essencial nas relações com o outro. O tradutor é um intermediário exemplar que torna possível o conhecimento de uma literatura não apenas engendrada em outra língua, mas também de costumes e dados culturais veiculados pelo texto traduzido (CARVALHAL, 2003, p. 238).

É nesse sentido que a tradução pode ser considerada atividade fundamental nas relações com o outro e, por sua própria ética, destinada a um problema da fidelidade. Como exercício histórico, literário e estético, a tradução pressupõe uma ética do ato de escrita e de transmissão, conforme os postulados bermanianos. Logo, cabe à teoria da tradução o esclarecimento dessa visada ética e, por conseguinte, o descarte de qualquer leitura que tome a tradução como mera redução de um texto anterior, tendo em vista que, no campo do domínio ético, o não apagamento da estrangeiridade da obra traduzida torna-se, via de regra, bem-vindo. Para corroborar tais princípios, Berman reconhece a necessidade de uma analítica do próprio tradutor, que deve "recuperar os sistemas de deformação que ameaçam a sua prática e operam de modo inconsciente no nível de suas escolhas linguísticas e literárias" (BERMAN, 2002, p. 20). Essa analítica deve ser plural, um trabalho de análise aberto (não solitário) do traduzir, pois sempre há, no horizonte da tradução, uma análise textual efetuada: "todo texto a ser traduzido apresenta uma sistematicidade própria que o movimento da tradução encontra, enfrenta, revela" (BERMAN, 2002, p. 20).

Tal analítica, sob essa égide, deve ser acrescida à ética da tradução. Rosemary Arrojo (1993), quando apresenta uma leitura do Pierre Mendard de Borges, declara que, apesar do eterno desejo de fidelidade do tradutor frente ao outro durante o processo de tradução, não há como separar o sujeito que traduziu daquilo que foi traduzido. Em outros termos, se traduzir é uma das maneiras mais atentas de ler e escrever (DERRIDA, 2000), à tarefa da tradução subjaz uma transferência que coloca o tradutor na condição de sujeito enamorado, pois "ler [traduzir] é sempre uma forma de se estar apaixonado" (ARROJO, 1993, p. 158). Com base nessas premissas, se o texto a ser traduzido for colocado em uma das pontas da relação transferencial e o tradutor na outra delas, a tradução por ele efetuada estará, desde sempre, marcada por algo que o tradutor desejava e precisava dizer. Conforme Arrojo

[...] ler ou traduzir um texto é também uma forma de estar em análise, uma forma de se estar submetido à sedução e ao desejo do outro e de comunicar 0 deleite e 0 conflito envoltos nesse caso de amor. Se essa relação se dá dentro de um enredo de sedução e desejo, se dá também a partir de uma cena de violência e luta. Assim, o contato com o texto sempre envolve um desejo de possuir um saber que se atribui inicialmente a outrem e é a partir desse desejo que nascem não apenas a leitura e a tradução, mas, também, a escritura (ARROJO, 1993, p. 160, grifos nossos).

As assertivas de Arrojo são compreensíveis, em sua inteireza, se a tradução for vista como uma tentativa de o tradutor captar um saber pertencente ao 
outro. Nessa esfera, a fidelidade do tradutor, distante da lógica logocêntrica, continua, ambivalentemente, direcionada a mais de um: ora volta-se à obra e à língua estrangeiras, ora à língua e ao desejo do próprio tradutor. Em uma consideração mais radical, assim como defendido por Marta Marín-Dòmine (2015), o tradutor se volta aos textos e "o ponto de 'partida' é o seu desejo" (MARÍN-DÒMINE, 2015, p. 32). Em oposição a uma ilusória invisibilidade, a ética da tradução reclama uma responsabilidade do tradutor, a qual "não lhe poupa do destino inevitável da tradução: ser o produto de uma transformação pelo fato mesmo da falta de relação equivalente entre significantes de uma e outra língua" (MARÍN-DÒMINE, 2015, p. 229). Portanto, o tradutor, ao se deparar com a impossibilidade do redizer total, faz do movimento tradutório uma experiência da falta que impulsiona o desejo de tradução. É nesse ângulo que "a própria atividade de traduzir pode ser vista como a causa do desejo, se entendermos textos de partida como representações imaginárias do objeto perdido" (MARÍN-DÒMINE, 2015, p. 232).

Arrojo (1993), em estudo sobre a tradução francesa do primeiro volume das Obras Completas de Sigmund Freud, afirma ser a compulsão o ponto de partida de todo e qualquer processo tradutório no horizonte da relação entre o objeto-texto a ser traduzido e o sujeito-tradutor. Esse emaranhamento, como quer Arrojo (1993, p. 38), concede à tradução um caráter transferencial sui generis, que ressalta a presença de uma pulsão, um prazer ou um desejo na mola propulsora de qualquer ato tradutório. Em outros termos, "pode-se dizer que ao invés de uma transferência impessoal de significados, qualquer tradução reproduz uma relação transferencial entre tradutor e texto e entre tradutor e autor" (ARROJO, 1993, p. 38), no meio da qual encontramos sentimentos contraditórios e convergentes. Nessa relação, o texto a ser traduzido assume um papel ativo atribuído por seu turno pelo tradutor, ou seja, texto e tradutor travam um jogo performativo de leitura que emerge da experiência tradutória, pois "qualquer forma de escritura [...], seja ela a escritura de uma teoria ou de uma tradução, é, em algum nível, também a escritura de uma autobiografia" (ARROJO, 1993, p. 43).

Em meio às suas observações sobre a analítica da tradução, Berman (2002) concebe a visada ética como o transbordamento dessa pulsão tradutória, aproximando-se da perspectiva de Arrojo (1993) e Marín-Dòmine (2015), as quais tomam o desejo como fundamento básico e primeiro da tradução. Porém, ampliando esse pressuposto, o crítico francês alega que, ao se realizar enquanto pulsão, o ato tradutório ultrapassa o estágio do desejo secreto abrindo-se a um diálogo entre o familiar e o estranho, o semelhante e o diferente, o próprio e o estrangeiro, passando a ser ético, poético e filosófico o objetivo profundo da tradução literária. Berman designa esse objetivo ético por meio de dois termos-chave: fidelidade e exatidão, os quais

[...] se referem a uma certa postura do homem em relação a si mesmo, aos outros, ao mundo e à existência. $E$, do mesmo modo, certamente, com relação aos textos. $\mathrm{Na}$ sua área, o tradutor é tomado pelo espírito de fidelidade e de exatidão. É a sua paixão, e é uma paixão ética (BERMAN, 2013, p. 95, grifo do autor).

A noção de fidelidade da tradução literária, em Berman, está atravessada, entre outros exemplos, pela forma como Hölderlin se mostrou fiel não somente aos textos que traduziu, mas também ao contexto a partir do qual realizou suas traduções, tendo em vista que, para o poeta, a tradução foi concebida como um dos movimentos básicos da formação cultural de seu povo. Enviesado pelo projeto da Bildung da Alemanha romântica e clássica, Hölderlin, com a tradução da Antígona, de Sófocles, provou o estrangeiro em sua estranheza e, ao mesmo tempo, propôs uma aprendizagem do próprio (a língua, a literatura e a cultura alemãs). Talvez por isso Haroldo de Campos (1975) tenha sugerido que, embora mal apreciadas por alguns de seus contemporâneos, as traduções feitas por Hölderlin veiculavam um sentido outro de fidelidade. O que alguns apontaram como erro, equívoco ou falta de conhecimento, Campos nomeou como "erros criativos" (CAMPOS, 1975, p. 97), ampliando a noção de fidelidade e atribuindo a Hölderlin a alcunha de "poeta-tradutor" exegeta, espécie de hermeneuta ocupado com a linguagem 
enquanto rito sagrado, poeta que fez de sua versão alemã da Antígona uma verdadeira reescritura da informação estética de um texto literário outro, uma reapresentação do sistema de signos da tragédia clássica de Sófocles ${ }^{3}$.

O objetivo ético da tradução, sob esse ângulo, "consiste em reconhecer e receber o Outro enquanto Outro" (BERMAN, 2013, p. 95), acolher o estrangeiro em sua diferença, sem movimentos de rejeição ou dominação, para além de princípios imperativos, ou seja, esse objetivo só se concretiza no campo dialógico. Vale ressaltar que esta ética nem sempre foi praticada na história do Ocidente, que, com frequência, estabeleceu elos de fidelidade na ordem de uma política do mesmo e do semelhante. É sob o prisma dos vínculos que a tradução passa a ocupar um espaço de destaque nas relações entre homens, línguas e culturas, afastando-se dos ditames de uma equivalência que se quis total em nome do equivocado repúdio às diferenças. Assim, "a tradução, com seu objetivo de fidelidade, pertence originalmente à dimensão ética. Ela é, na sua essência, animada pelo desejo de abrir o Estrangeiro enquanto Estrangeiro ao seu próprio espaço de língua" (BERMAN, 2013, p. 97, grifos do autor), "abrir" no sentido de revelar, manifestar, conforme declara o crítico francês, fazer do ato tradutório uma manifestação enquanto tal de uma obra anterior.

Os fundamentos bermanianos sobre ética na tradução literária encontram, acautelados os distanciamentos, respaldo na lei da hospitalidade tal como desenvolvida por Derrida em vários de seus textos. Para ele, o princípio da hospitalidade é "uma questão vinda do estrangeiro" (DERRIDA, 2003, p. 5), do texto estrangeiro a ser traduzido, sendo este aquele que interpela o outro (tradutor) a respeito de sua própria estrangeiridade por não falar a língua desse outro, causando uma espécie de combate (questão, guerra interna) dentro dos discursos e das falas. Além de tudo, o texto estrangeiro é alheio à própria língua

\footnotetext{
3 Para um aprofundamento da importância histórica das traduções empreendidas por Hölderlin, conferir os seguintes ensaios de Antoine Berman e Haroldo de Campos, respectivamente: "Hölderlin: o nacional e o estrangeiro" (BERMAN, 2002, p. 281-312), "Hölderlin, ou a tradução como manifestação" (BERMAN, 2013, p. 103-125), "A palavra
}

em que uma literatura, cultura ou nação formula o direito ao asilo, tornando-se o pedido de hospitalidade uma fala a ser pronunciada na língua do outro, pedido esse que se realiza tão somente por meio da tradução, um verdadeiro direito à literatura estrangeira que continua sendo estrangeira: o direito da hospitalidade e do acolhimento. É operante ressaltar que o estrangeiro, na concepção derridiana, é uma alteridade que suplica o direito a uma morada, pois, "para começar, o direito à hospitalidade pressupõe uma casa" (DERRIDA, 2003, p. 21). Dito de outro modo, o estrangeiro é um estranho que, na dimensão ética da tradução literária, solicita o "albergue do longínquo" (BERMAN, 2013, p. 97).

Entretanto, a hospitalidade incondicional mediada pela tradução rompe com o direito tal como formulado pela língua que alberga o estrangeiro, tendo em vista que a hospitalidade da justiça (a tradução) rompe com a hospitalidade de direito. Em outras palavras,

[...] a hospitalidade absoluta exige que eu abra a minha casa e não apenas ofereça ao estrangeiro (provido de um nome de família, de um estatuto social de estrangeiro, etc.), mas ao outro absoluto, desconhecido, anônimo, que eu lhe ceda lugar, que eu o deixe vir, que o deixe chegar, e ter um lugar no lugar que ofereço a ele, sem exigir dele nem reciprocidade (a entrada num pacto), nem mesmo seu nome. A lei da hospitalidade absoluta manda romper com a hospitalidade de direito, com a lei ou a justiça como direito [...] (DERRIDA, 2003, p. 23-24, grifo do autor).

Nesse sentido, se concebermos a tradução literária enquanto ato ético por excelência frente ao outro, podemos postular que uma literatura, ao traduzir esse outro em sua estrangeiridade absoluta, cede-lhe lugar em sua própria cultura e, simultaneamente, permite a vinda de uma literatura estranha sem dela nada exigir. É interessante notar que Derrida grifa, na passagem acima transcrita, a expressão "ceder lugar", como se indicasse ser o ato tradutório uma ação ética da boa acolhida, da

vermelha de Hoelderlin" (CAMPOS, 1975, p. 93-107) e "A clausura metafísica da teoria da tradução de Walter Benjamin, explicada através da Antígone de Hölderlin" (CAMPOS, 2015, p. 173-196). 
acolhida inquestionável do outro antes de qualquer inquérito a respeito de seu nome estrangeiro. É como se o tradutor literário possibilitasse ao texto a ser traduzido o proclame de uma voz estranha no seio de outra literatura, fazendo do tradutor-hospedeiro e do texto-hóspede ${ }^{4}$ em tradução atores em uma cena de hospitalidade. Na prática, uma mise en scène da tradução em que o tradutor, por seu turno, cede lugar a uma literatura estrangeira levada a atuar por meio de uma língua que não a sua, mas sem o apagamento das marcas de sua própria dicção. Sob a égide de tais conjecturas, "o estrangeiro é entendido a partir do campo circunscrito do ethos ou da ética" (DERRIDA, 2003, p. 39), em nosso caso, da ética na tradução literária.

Ao invés de provocar uma descaracterização no interior da literatura hospitaleira, a tradução, enquanto movimento ético, auxilia, a propósito, no arranjo do espaço identitário dessa literatura, tendo em vista o realce da diferença. Verdade seja dita: não há identidade linguística, literária ou cultural que se constitua na xenofobia pelo estrangeiro, quer dizer, "para constituir o espaço de uma casa habitável, é preciso também uma abertura, uma porta e janelas, é preciso dar passagem ao estrangeiro" (DERRIDA, 2003, p. 55, grifos nossos). Desse modo, a tradução como abertura, diálogo e reescrita, semelhantemente aos pressupostos defendidos por Berman, propicia à literatura acolhedora um exercício de autocrítica do qual não se pode renunciar quando o horizonte é o da concepção ética. Ademais, é por meio desse exercício frente ao outro que a tradução pode também disseminar novas orientações estéticas a partir de seu princípio ético da hospitalidade, além de potencializar procedimentos criativos em contextos de recepção.

A diferença, ao invés de afastar diametralmente os agentes postos em relação (texto estrangeiro e texto traduzido, literatura estrangeira e literatura nacional, língua estranha e língua local,

\footnotetext{
4 O sentido de "texto-hóspede" tal como empregado aqui segue aquele proposto por Derrida (2003, p. 53) na distinção entre hóspede e parasita. O filósofo afirma que o parasita nunca está submetido a um acolhimento, pois aquele que chega só é recebido na circunstância como hóspede quando beneficiário do direito da hospitalidade. De outro modo, "sem esse direito ele só
}

autor e tradutor, entre outros), acaba por esclarecer a necessidade da tradução enquanto resposta ao outro. No campo da diferença ética, o tradutor assume uma responsabilidade que não toma "sobre si ou para si a direção, a custódia ou o destino do outro" (SISCAR, 2012, p. 163). Essa responsabilidade tem algo a ver com a resposta ao chamado do outro, ao questionamento do estrangeiro, "como se o estrangeiro fosse, primeiramente, aquele que coloca a questão ou aquele a quem se endereça a primeira questão" (DERRIDA, 2013, p. 5, grifos do autor). Tal responsabilidade "pode ser entendida como momento ético da tradução, como momento crítico no sentido de crise da escolha, assunto de fato pouco sublinhado e que tem consequências reais na prática da tradução" (SISCAR, 2012, p. 163, grifo do autor).

No horizonte do movimento de hospitalidade incondicional, a tradução assume seu papel crítico (de crise) frente a um texto estrangeiro, não somente no sentido de apenas chamar pelo outro, mas de dizer a esse outro: “entre', entre sem esperar, faça uma parada entre nós sem esperar" (DERRIDA, 2013, p. 107); de dizer à literatura estrangeira: "entre" em nossa casa, em nossa língua, faça aqui morada. Essa resposta ou responsabilidade ética, na acepção derridiana do termo, move a conduta do ato hospitaleiro sem reservas, seja por meio da língua ou de algo endereçado ao estrangeiro. No caso específico da tradução literária, o trabalho corpóreo da letra (Berman) ou da palavra (Derrida) em tradução é o elemento que torna possível um discurso responsável dirigido ao outro acompanhado da oferta de uma estadia em terras estranhas. Por isso, o problema da hospitalidade torna-se“"...] coextensivo ao problema ético. Trata-se de engajarse em favor de uma morada, de sua identidade, de seu espaço, de seus limites, do ethos enquanto estada, habitação, casa, residência, família, chezsoi" (DERRIDA, 2003, p. 131, grifos do autor).

pode introduzir-se 'em minha casa' de hospedeiro, no chez-soi do hospedeiro (host), como parasita, hóspede abusivo, ilegítimo, clandestino, passível de expulsão ou detenção" (DERRIDA, 2003, p. 53). 
Em consequência, se concebida pelo crivo de uma ética da hospitalidade incondicional, a tradução se firma enquanto fenômeno literário responsável por conceder residência a uma literatura estrangeira, a um texto estranho, a uma língua outra. A língua, em sentido mais amplo, como "aquela com a qual se dirige ao estrangeiro ou com a qual se ouve-o, é o conjunto da cultura" (DERRIDA, 2003, p. 115) não enclausurado entre fronteiras. É a partir desse ponto de vista que o ato ético da tradução se aproxima da ética da hospitalidade derridiana, pois o recebimento do estrangeiro sem reservas, assim como a tradução,

[...] consiste em fazer tudo para se dirigir ao outro, em lhe conceder, até mesmo perguntar seu nome, evitando que essa pergunta se torne uma "condição", um inquérito policial, um fichamento ou um simples controle das fronteiras. Diferença de uma só vez sutil e fundamental, questão que se coloca no limiar do "em-casa" e no limiar entre duas inflexões. Uma arte e uma poética, mas também toda uma política dependem disso, toda uma ética se decide aí (DERRIDA, 2004, p. 250, grifo nosso).

Portanto, tratar da tradução literária em múltiplos contextos é, em amplo sentido, uma forma de falar sobre o mundo e a linguagem, o homem e as suas produções, já que ele não deixa ser um sujeito em tradução, constituído em um processo contínuo, um "vaivém incessante, de dentro para fora, da violência à consciência: a produção do sujeito ético" (SPIVAK, 2005, p. 44), que dá vida a um idioma cultural, permitindo a performance do que se chama teatro, literatura, arte, cultura e até mesmo teoria. Não por acaso Derrida declarou, certa vez, sua "admiração por aqueles e aquelas que considero[u] os únicos a saber ler e escrever: as tradutoras e [os] tradutores" (DERRIDA, 2000, p. 14). Enquanto de um lado a tradução veicula um problema de ordem metafísica, como bem fundamentado pelo pensamento benjaminiano, de outro, aciona também um ato físico e humano ou, como entende Haroldo de Campos (2005, p. 181), "um índice do fazer". Esse fazer corresponde a uma física da tradução que, por sua vez, fundamenta-se no ato de retraçar um percurso poético anterior na língua e na literatura para as quais se traduz. O princípio haroldiano da física do traduzir apoia-se na premissa de que a tradução de um texto literário é, grosso modo, um ato de recriar a função poética presente em um texto estrangeiro, um texto estranho, passando a ser o tradutor uma espécie de

[...] coreógrafo da dança interna das línguas, tendo o sentido [...] não como meta linear de uma corrida termo-a-termo, sineta pavloviana da retroalimentação condicionada, mas como bastidor semântico ou cenário pluridesdobrável dessa coreografia móvel. Pulsão dionisíaca, pois dissolve a diamantização apolínea do texto original já pré-formado numa nova festa sígnica: põe a cristalografia em reebulição de lava (CAMPOS, 2005, p. 181).

Não deixa de estar implícita, na metáfora da tradução enquanto coreografia móvel, a presença da dimensão ética do ato tradutório e de sua visada crítica. Em entrevista concedida a Rodrigo Figueira Naves, publicada originalmente no "Folhetim Erudição" do jornal Folha de São Paulo, em 21 de agosto de 1983, Campos, além de responder algumas perguntas voltadas à poética da poesia concreta, demarca o seu lugar de escritor fora do centro e tece alguns comentários sobre a eficaz prática transculturadora e transcriativa dos escritores latino-americanos inclinados a um diálogo mais próximo com a tradição estrangeira. O poeta-tradutor afirma que a prática da tradução realizada pelos concretistas brasileiros evidenciou, efetivamente, a importância da relação existente entre o dispositivo criador e o ato de tradução, além de propagar novas ideias e poéticas que ajudariam, ainda mais, reforçar e dar a conhecer uma tradição até certo ponto desconhecida. Nas palavras de Campos, "[...] a tradução, melhor dizendo, a transcriação da poesia de várias latitudes e tempos, foi o nosso dispositivo transculturador preferencial. Uma atividade tradutora provida de projeto crítico [...]" (CAMPOS, 2010, p. 266, grifo do autor).

É sob esse prisma que a tradução em sua visada ética e hospitaleira se abre ao outro para fecundar o próprio, seja ele uma língua, uma literatura, um projeto estético, enfim, uma cultura. Foi nesse sentido que Campos entendeu a tradução 
enquanto atividade crítica que pode também nutrir o impulso criador de escritores de determinada literatura quando tradutores. Apoiados no ato do traduzir como tarefa que engendra uma atitude ética, os contemporâneos Estudos da Tradução passaram também a considerar a perspectiva do tradutor (sujeito produtor de linguagem em contextos sociais, históricos e culturais); a relevância da noção de hibridismo, transculturação e transferência; a associação do ato tradutório à circulação material de pessoas em contextos diaspóricos; a tradução como atividade que questiona as fronteiras estabelecidas sejam elas de quaisquer naturezas (Cf. PYM, 2017, p. 273). Por essas razões, a tradução e o papel ético dos tradutores passaram a integrar o rol de interesse de diversas áreas do conhecimento, tornando-se matéria de perspectivas literárias, filosóficas, históricas, psicanalíticas, entre outras, como aqui procuramos evidenciar com base em postulados construídos a partir de proposições que dialogam em suas diferenças.

Da tradução literária enquanto atividade humana e objeto transdisciplinar por excelência, manifesta-se, conforme discorremos, uma ética por si só atravessada pelo modus operandi do homem na história e pela forma como as línguas, literaturas e culturas se constituem e se renovam infinitamente. Assim, o ato de traduzir (quiçá movimento mais íntimo de paixão e de abertura frente ao estranho) ultrapassa os meandros da simples transposição e se abre ao acolhimento do outro, do estrangeiro em seu próprio corpo estrangeiro, propiciando, como sugerido nas passagens epigráficas transcritas no início deste texto, um movimento de amor e de carícia entre o corpo das línguas, dos homens e das culturas. À guisa de término destas notas, podemos dizer, por ora, que a ética na tradução literária se sustenta na bem-aventurança dos liames entre corpos estrangeiros, entre materialidades textuais estranhas que se experimentam e se (auto)definem. No corpo das línguas (Derrida), no corpo das obras (Berman), a tradução literária se firma como fenômeno (est)ético que não se pode dispensar.

\section{REFERÊNCIAS}

ARROJO, Rosemary. Tradução, desconstrução e psicanálise. Rio de Janeiro: Imago, 1993. 212 p. (Biblioteca Pierre Menard)

BENJAMIN, Walter. A tarefa do tradutor. Tradução de Susana Kampff Lages. In: HEIDERMANN, Werner (Org.). Clássicos da teoria da tradução. $2^{\underline{a}}$ ed. Florianópolis: UFSC /Núcleo de Pesquisas em Literatura e Tradução, 2010. (v. 1. Alemão-Português). 344 p. p. 203-231.

BERMAN, Antoine. A prova do estrangeiro: cultura e tradução na Alemanha romântica: Herder, Goethe, Schegel, Novalis, Humboldt, Schleiermacher, Hölderlin. Tradução de Maria Emília Pereira Chanut. Bauru, SP: EDUSC, 2002. 356 p.

BERMAN, Antoine. A tradução e a letra ou o albergue do longínquo. Tradução de Marie-Hélène C. Torres et. al. Tubarão: Copiart; Florianópolis: PGET/UFSC, 2013. $200 \mathrm{p}$.

BORGES, Jorge Luis. Ficções. Tradução de Davi Arrigucci Jr. São Paulo: Companhia das Letras, 2007. $169 \mathrm{p}$.

CAMPOS, Haroldo. Metalinguagem e outras metas: ensaios de teoria e crítica literária. $4^{\underline{a}}$ ed. São Paulo: Perspectiva: 2010. 311 p. (Debates)

CAMPOS, Haroldo. A palavra vermelha de Hoelderlin. In: A arte no horizonte do provável e outros ensaios. São Paulo: Perspectiva, 1975. p. 93-107. 237 p. (Debates)

CAMPOS, Haroldo. A clausura metafísica da teoria da tradução de Walter Benjamin, explicada através da Antígone de Hölderlin. In: Transcriação. Org. de Marcelo Tápia e Thelma M. Nóbrega. São Paulo: Perspectiva, 2015. p. 173-196. 256 p. (Estudos)

CAMPOS, Haroldo. Post Scriptum / Transluciferação Mefistofáustica. In: Deus e o diabo no Fausto de Goethe: marginália fáustica. São Paulo: Perspectiva, 2005. 209 p. (Signos)

CARVALHAL, Tania F. Tradução e recepção na prática comparatista. In: O próprio e o alheio: ensaios de literatura comparada. São Leopoldo (RS): Editora Unisinos, 2003. 264 p. p. 217-264.

DERRIDA, Jacques. Torres de babel. Tradução de Junia Barreto. Belo Horizonte: Editora UFMG, 2002. 74 p.

DERRIDA, Jacques. O que é uma tradução 'relevante'? Tradução de Olivia Niemeyer Santos. Alfa: Revista de Linguística, Edição especial Tradução, desconstrução e pós-modernidade, São Paulo, v. 01, n. 44, p. 14-44, $2000 . \quad$ Disponível em: 
Do estrangeiro em sua corporeidade: notas sobre ética na tradução literária.

http://seer.fclar.unesp.br/alfa/article/view/4277. Acesso em 16.04.2021.

DERRIDA, Jacques. Questão do estrangeiro: vinda do estrangeiro. In: DERRIDA, Jacques; DUFOURMANTELLE, Anne. Anne Dufourmantelle convida Jacques Derrida a falar da hospitalidade. Tradução de Antonio Romane; Revisão técnica de Paulo Ottoni. São Paulo: Escuta, 2003. p. 05-65. 135 p.

DERRIDA, Jacques. Nada de hospitalidade, passo da hospitalidade. In: DERRIDA, Jacques; DUFOURMANTELLE, Anne. Anne Dufourmantelle convida Jacques Derrida a falar da hospitalidade. Tradução de Antonio Romane; Revisão técnica de Paulo Ottoni. São Paulo: Escuta, 2003. p. 67-135. 135 p.

DERRIDA, Jacques. O princípio da hospitalidade. In: Papel-máquina. Tradução de Evando Nascimento. São Paulo: Estação Liberdade, 2004. p. 249-252. 360 p.

DERRIDA, Jacques. Fidelidade a mais de um: merecer herdar onde a genealogia falta. In: OTTONI, Paulo. Tradução manifesta: double bind \& acontecimento. Campinas, SP: Editora da Unicamp; São Paulo, SP: Edusp, 2005. 198 p. p. 167-198.

LISPECTOR, Clarice. A descoberta do mundo. Rio de Janeiro: 1999. $199 \mathrm{p}$.

MARÍN-DÒMINE, Marta. Traduzir o desejo: psicanálise e linguagem. Tradução de Emiliano de Brito Rossi. Belo Horizonte: Editora UFMG, 2015. 246 p. (Humanitas)

PIGLIA, Ricardo. Memoria y tradición. In: 2o CONGRESSO ABRALIC, 1990, Belo Horizonte. Anais do $2^{\circ}$ Congresso da Abralic - Literatura e memória cultural. Belo Horizonte: UFMG, 1991. p. 60-66.

PYM, Anthony. Explorando teorias da tradução. Tradução de Rodrigo Borges et. al. São Paulo: Perspectiva, 2017. 336 p.

SANTIAGO, Silviano. Glossário de Derrida. Rio de Janeiro: Francisco Alves, 1976. 100 p.

SISCAR, Marcos. Jacques Derrida: literatura, política e tradução. Campinas: Autores Associados, 2012. 216 p.
SPIVAK, Gayatri Chakravorty. A tradução como cultura. Ilha do desterro: Revista de Língua Inglesa, Literaturas em Inglês e Estudos Culturais, Florianópolis, n. 48, p. 41-64, 2005. Disponível em: https://periodicos.ufsc.br/index.php/desterro/article/view /9833/9064. Acesso em 16.04.2021.

CARDOSO FERREIRA, Rony Márcio. Do estrangeiro em sua corporeidade: notas sobre ética na tradução literária. Signo, Santa Cruz do Sul, v. 46, n. 87, sep. 2021. ISSN 1982-2014. Disponível em: <https://online.unisc.br/seer/index.php/signo/article/view/1 6497>. doi:https://doi.org/10.17058/signo.v46i87.16497. 